\title{
UTJECAJ STARENJA STANOVNIŠTVA NA PROMJENE ZEMLJIŠNOG POKROVA/NAČINA KORIŠTENJA ZEMLJIŠTA SREDNJE LIKE
}

\author{
Marta Hamzić \\ Ericsson Nikola Tesla d.d. \\ Krapinska 45 \\ HR 10000 Zagreb \\ marta.jovanic@gmail.com \\ Ivo Turk \\ Institut društvenih znanosti Ivo Pilar \\ Marulićev trg 19 \\ HR 10000 Zagreb \\ ivo.turk@pilar.hr
}

UDK: 316.66-053.9(497.5)

314(497.5Lika)

Izvorni znanstveni članak

Ur.: 2021-08-19

\begin{abstract}
Utjecaj starenja stanovništva na promjene zemljišnog pokrova/načina korištenja zemljišta Srednje Like u radu je analiziran korištenjem interdisciplinarnog pristupa analizom rezultata provedenog anketnog ispitivanja na uzorku ispitanika Srednje Like i demo(geo)grafskom analizom podataka koji se odnose na dobnu strukturu stanovništva Srednje Like. Međuodnosi zemljišnog pokrova/načina korištenja zemljišta i dobi ispitanika analizirani su na prostornoj razini Srednje Like u cjelini korištenjem metode t-test u sklopu računalnog programa IBM SPSS Statistics verzije 20. Rezultati su pokazali kako se položaj povrtnjaka, posjedovanje obradivog zemljišta u dragama i tendencija obrađivanja zemljišta u dragama razlikuju ovisno o dobi ispitanika.
\end{abstract}

Ključne riječi: starenje stanovništva, zemljišni pokrov/način korištenja zemljišta, krajolik, razvoj krajolika, Srednja Lika

\section{Uvod}

Značajno preoblikovanje krajolika počelo je naseljavanjem stanovništva. Od tada, kako bi najbolje zadovoljili svoje životne i ekonomske potrebe, ljudi kontinuirano preoblikuju krajolik, pa krajolici "doprinose oblikovanju lokalnog i regionalnog identiteta te reflektiraju povijest kao i koegzistenciju ljudi i prirode."

${ }^{1}$ J. HERNIK, 2009, 20. 
Time su danas gotovo svi krajolici na Zemlji zapravo kulturni krajolici², nastali kao rezultat procesa njihovog preoblikovanja u prošlosti i danas, zbog čega se može usporediti kako su "krajolici kao palimpsest, pergament u kojeg su se upisivali različiti tekstovi, pri čemu je svaki ostavio svoje tragove." ${ }^{13}$

Ako se promatra da je krajolik "područje percipirano od ljudi čiji je karakter rezultat djelovanja i međudjelovanja prirodnih $\mathrm{i} / \mathrm{ili}$ ljudskih čimbenika", ${ }^{4}$ tada krajolik nije samo fizička, nego je i mentalna tvorba ${ }^{5}$ uvjetovana asocijativnim obilježjima krajolika, ${ }^{6}$ odnosno kulturom u kojoj smo socijalizirani i obrazovani ${ }^{7}$ te mjestom življenja i vrstom gospodarske aktivnosti kojom se bavimo. Stoga se zbog obuhvatnosti i fleksibilnosti "istraživanjima krajolika treba pristupiti kao interdisciplinarnome području". ${ }^{8}$

U ovom se radu krajolik promatra kroz koncept zemljišnog pokrova/ načina korištenja zemljišta te se proučava utjecaj starenja stanovništva na promjene zemljišnog pokrova/načina korištenja zemljišta, odnosno na razvoj krajolika Srednje Like. Naime, u ovom se radu polazi od pretpostavke kako je starenje stanovništva nepovoljni čimbenik promjene zemljišnog pokrova/ načina korištenja zemljišta Srednje Like te da ima (nepovoljni) utjecaj u smislu smanjenja intenziteta obrade, što posljedično dovodi do zapuštanja krajolika. U tu svrhu je provedena analiza rezultata anketnog ispitivanja o zemljišnom pokrovu/načinu korištenja zemljišta na uzorku ispitanika Srednje Like, kako bi se promotrio utjecaj starenja na zemljišni pokrov/ način korištenja zemljišta, odnosno na njegovu promjenu. Rezultati anketnog ispitivanja analizirani su s obzirom na dob ispitanika. Pri tome je $u$ istraživanju korišten pristup analize rezultata anketnog ispitivanja za dvije prostorne razine (analizirana grupa i Srednja Lika u cjelini), koji su promatrani za dvije različite vremenske odrednice - trenutačno/u vrijeme anketnog ispitivanja te u dužem vremenskom razdoblju koje je prethodilo anketnom ispitivanju. Tako su s obzirom na vremensku odrednicu trenutačno/u vrijeme anketnog ispitivanja analizirani položaj voćnjaka i povrtnjaka te posjedovanje obradivog zemljišta u dragama. ${ }^{9}$ Naime, oni su promatrani kao pojedinačni

\footnotetext{
${ }^{2}$ M. HAMZIĆ et al., 2020, 14-15.

${ }^{3}$ A. VAN DER WALK, 2009, 34.

${ }^{4}$ B. DUMBOVIĆ BILUŠIĆ, 2015, 22.

${ }^{5}$ B. DUMBOVIĆ BILUŠIĆ, 2015, 1-346.

${ }^{6}$ A. SOPINA et al., 2015, 304-313.

${ }^{7}$ B. KRIŠTOFIĆ, 2010, 273-300.

${ }^{8}$ B. DUMBOVIĆ BILUŠIĆ, 2014, 200.

${ }^{9}$ Draga je lokalni naziv za veću ponikvu ili uvalu.
} 
dijelovi krajolika kako bi se dobio uvid u obilježja njihovog posjedovanja i prostorne odnose te postoji li utjecaj starenja na njih. S druge strane, analiza kroz duže vremensko razdoblje prije anketnog ispitivanja odnosi se na njihovo održavanje te utječe li starenje stanovništva na njih. Navedeni međuodnosi analizirani su korištenjem metode t-test, u sklopu računalnog programa IBM SPSS Statistics verzije 20.

Zemljišni pokrov/način korištenja zemljišta, odnosno njegove promjene u dosadašnjim istraživanjima su promatrane kroz različite aspekte/ pristupe. Tako su, na primjer, autori Borna Fuerst-Bjeliš (2003.), Anica Čuka (2010.), Jelena Lončar i Marin Cvitanović (2012.) te Zdenka Damjanić (2014.) promatrali zemljišni pokrov/način korištenja zemljišta ponajviše kroz sociogeografske, odnosno socioekološke aspekte. S druge strane, zemljišni pokrov/način korištenja zemljišta prvenstveno kroz prostorno-analitički aspekt koristili su Stefan Lang i Thomas Blaschke (2010.), Luka Valožić i Marin Cvitanović (2011.), Sushant Paudel i Fei Yuan (2012.), Anamarija Durbešić (2012.), Tomislav Jogun te Aleksandar Lukić i Mateo Gašparović (2019.). Međutim, pojedini autori kao što su, na primjer, Borna Fuerst-Bjeliš et al. (2011., 2018., 2019., 2021.), Marin Cvitanović (2014.), Ante Blaće (2015., 2017.), Antonio Morić-Španić i Borna Fuerst-Bjeliš (2017.), Tomislav Jogun et al. (2017.) te Marta Jovanić (2017.) pri istraživanju (promjena) zemljišnog pokrova/načina korištenja zemljišta podjednako koriste različite vrste aspekata (npr. društveni, prostorno-analitički). Premda se istraživanja (promjena) zemljišnog pokrova/načina korištenja zemljišta, kako je vidljivo, sagledavaju iz različitih aspekata, odnosno pristupa, dosad nije detaljnije analiziran utjecaja starenja stanovništva na promjene zemljišnog pokrova/ načina korištenja zemljišta korištenjem kombinacije demo(geo)grafske analize i analize rezultata anketnog ispitivanja na uzorku ispitanika.

\section{Područje istraživanja}

Administrativno gledajući, Srednja Lika obuhvaća područje triju jedinica lokalne samouprave Ličko-senjske županije: Grad Gospić, Općinu Lovinac i Općinu Perušić, sa sjedištima u istoimenim naseljima (Sl. 1). ${ }^{10}$ Ukupna površina Srednje Like je oko $1690 \mathrm{~km}^{2}$, gdje je okupljeno ukupno 78 naselja (u Gradu Gospiću 50, Općini Perušić 18 i Općini Lovinac 10), među kojima je Gospić jedino urbano i ujedno najveće naselje (6575 stanovnika, 2011.).

${ }^{10} \mathrm{U}$ ovom radu je kao dio Srednje Like analizirana i Općina Lovinac, premda je u nekim radovima promatrana kao dio Južne Like (npr. D. PEJNOVIĆ, 1985; D. MAGAŠ, 2013). 


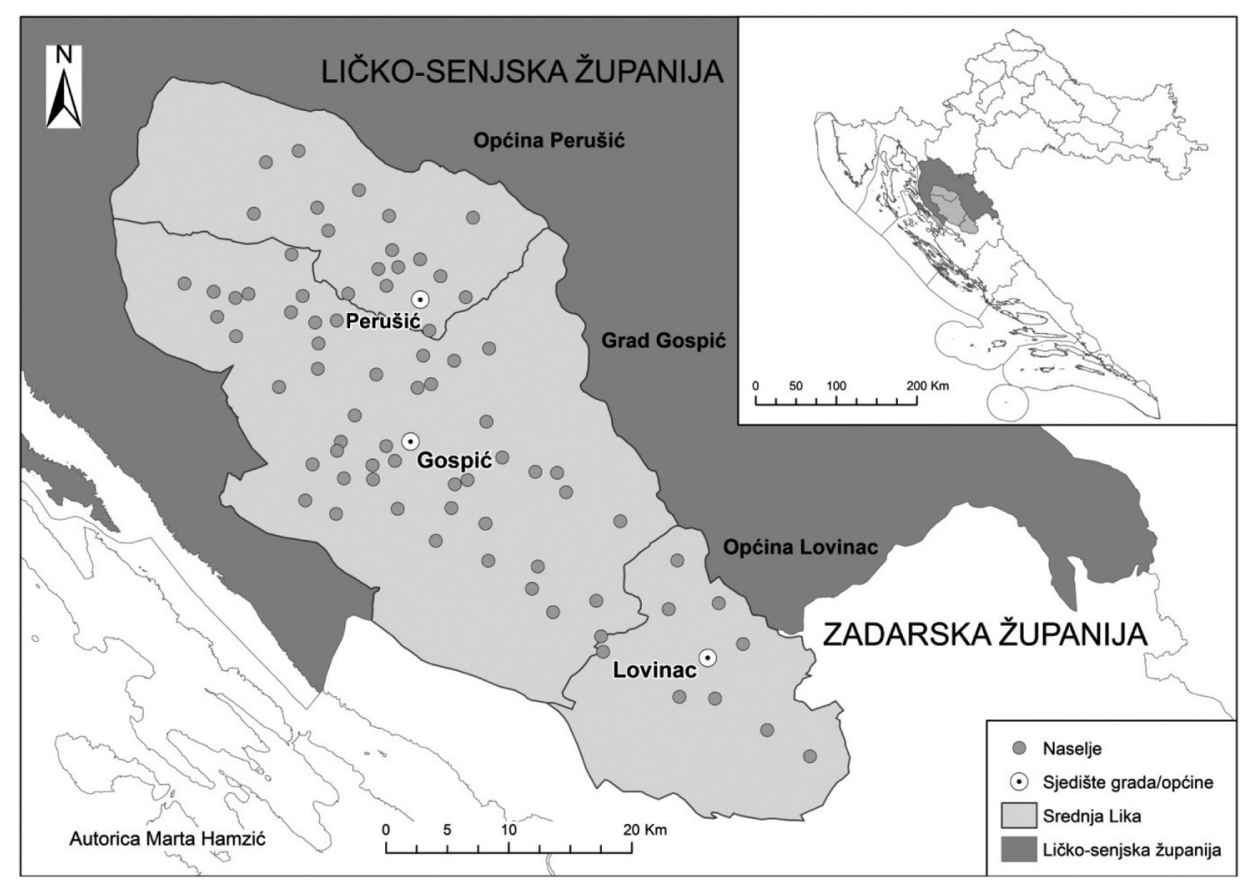

S1. 1. Područje istraživanja - Srednja Lika (izradila: M. Hamzić)

Osnovu regionalne izdvojenosti Srednje Like čini gorski hrbat Velebit sa zapadne i jugozapadne strane, Ličko sredogorje s istočne strane i gorski masiv Resnik s jugoistočne strane. ${ }^{11}$ Površinski najveći dio zavale Srednje Like zauzima Ličko polje, koje se smatra najvećim poljem u kršu na području Republike Hrvatske. Međutim, Ličko polje nije kontinuirana poljska zaravan, nego se sastoji od nekoliko manjih polja ${ }^{12}$ : Pazariško, Smiljansko, Bilajsko, Ribničko, Medačko, Ostrvičko i Osičko-širokokulsko. Sjeverno od Ličkog polja položena su polja Perušićko, Kosinjsko s udolinom Bakovac te Lipovo polje. Jugoistočni dio istraživanog područja zauzima Lovinačko polje, koje je od ostatka područja Srednje Like odvojeno kupastim humovima, odnosno uzvišenjima u kršu (Bukova glava 707 m, Kik 772 m, Zir 752 m, Debeljak 882 m). Od ostalih geomorfoloških oblika na području Srednje Like prisutne su ponikve, veće ponikve i uvale. ${ }^{13}$

\footnotetext{
${ }^{11}$ M. HAMZIĆ et al., 2020, 25-26.

${ }^{12}$ V. ROGIĆ, 1975, 7-64; D. PEJNOVIĆ, 1985, 187.

${ }^{13}$ Vidjeti bilješku 1.
} 


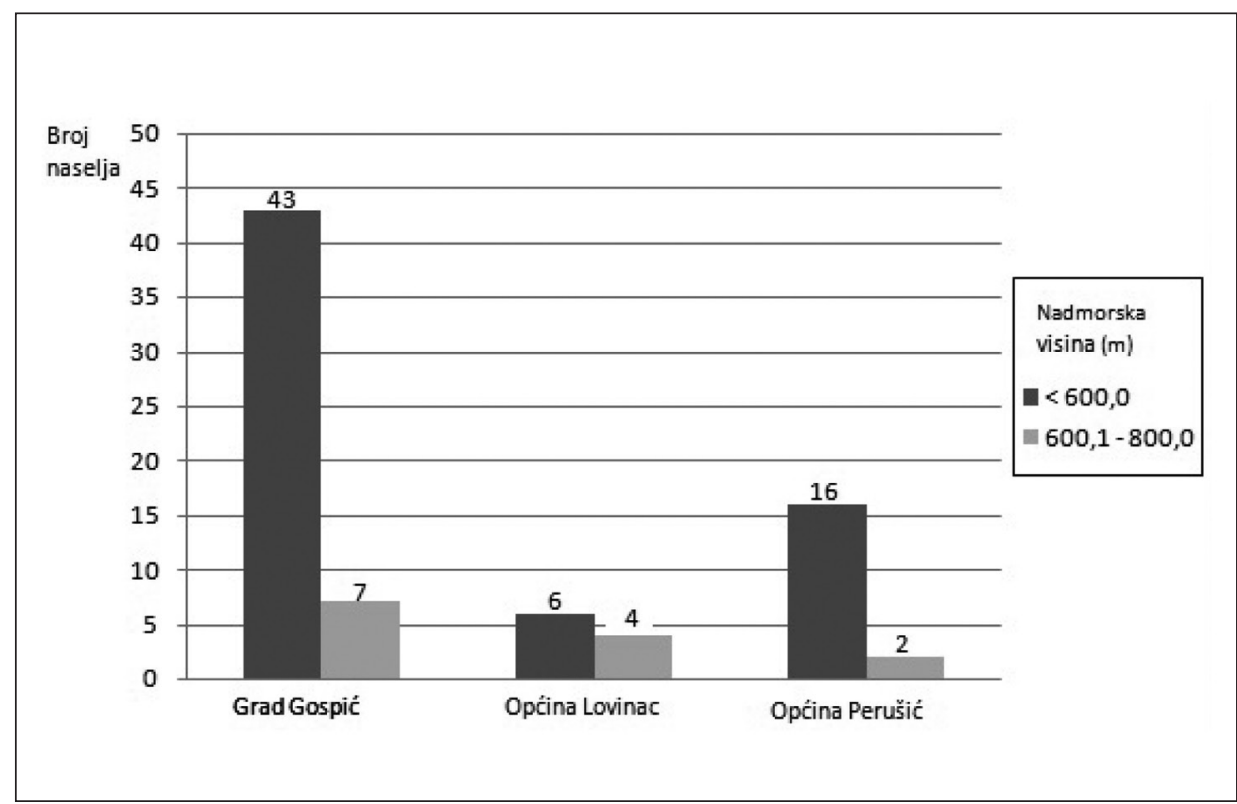

Sl. 2. Središta naselja Srednje Like prema nadmorskoj visini

(izvor: izračunato na temelju podataka iz baze podataka DARH (DGU) koja u sebi sadrži centroide koji se odnose na središta naselja i digitalni model visina tj. nadmorsku visinu Srednje Like)

Raspon nadmorske visine ukupnog područja Srednje Like je između 461 i 1757 m, a prosječna nadmorska visina iznosi 740 m. ${ }^{14}$ Naselja Srednje Like pretežno su položena na nižim nadmorskim visinama. Točnije, niti jedno naselje Srednje Like nema svoje središte na nadmorskoj visini višoj od 800 m n/v (Sl. 2).

\section{Metodologija i uzorak ispitanika}

\section{Metodološke napomene pri analizi popisnih podataka}

U svrhu demo(geo)grafske analize, u radu su korišteni popisni podaci Državnog zavoda za statistiku koji se odnose na ukupni broj stanovnika te na dobnu strukturu stanovništva prema posljednjem popisu (iz 2011.). Pri tome je potrebno napomenuti kako je taj popis, baš kao i onaj prije njega (iz 2001.) proveden prema prilagođenoj koncepciji uobičajenog mjesta stanovanja (engl.

${ }^{14}$ M. HAMZIĆ et al., 2020, 26-27 prema M. PAHERNIK - M. JOVANIĆ, 2014, 97. 
place of usual residence).${ }^{15}$ Budući da pouzdaniji demografski pokazatelji ne postoje, u namjeri što vjernijeg prikaza promatranih pokazatelja Srednje Like, službeni popisni podaci Državnog zavoda za statistiku u ovom radu su korišteni kao činjenični.

\section{Metodološke napomene pri analizi rezultata anketnog ispitivanja}

Anketno ispitivanje provedeno je u drugoj polovici 2013. godine. ${ }^{16}$ Uzorak provedenog anketnog ispitivanja sastoji se od 110 anonimnih ispitanika koji su odabrani jednostavnim slučajnim uzorkom metodom "na licu mjesta" (in situ). Pri tome se može reći kako je anketirano 110 kućanstava Srednje Like jer se većina pitanja odnosi na posjede kućanstava ispitanika. U cilju dobivanja što reprezentativnijeg uzorka, anketiranje je provedeno u odabranim naseljima (njih 21) koja su na području istraživanja ravnomjerno raspoređena $\mathrm{s}$ obzirom na različite uvjete (administrativno-teritorijalna podjela, karakteristike reljefa, udaljenost od autoceste i drugih prometnica). $\mathrm{U}$ ovom radu je obrađen samo dio od ukupno 25 postavljenih pitanja u anketnom upitniku. Anketni upitnici analizirani su računalnim programom IBM SPSS Statistics verzije 20. Rezultati anketnog upitnika analizirani su procedurama deskriptivne statistike. ${ }^{17}$ Također, pojedini međuodnosi dobi i zemljišnog pokrova/načina korištenja zemljišta koji su analizirani procedurama inferencijalne statistike, ${ }^{18}$ preciznije t-testom, provedeni su za prostornu razinu Srednje Like u cjelini.

Potrebno je naglasiti kako je analiza rezultata anketnog ispitivanja korištenjem procedura deskriptivne statistike provedena na dvije prostorne razine - Srednja Lika u cjelini i analizirana grupa. Naime, kako bi se uvidjelo postoje li razlike na nižim prostornim razinama, područje Srednje Like, odnosno naselja u kojima je provođeno anketno ispitivanje su raspoređena u tri grupe, čiji se nazivi koriste dalje u radu (Tab. 1). Prva grupa je grad Gospić i obuhvaća formalni grad Gospić, tj. odnosi se na jedino naselje gradskog tipa na području istraživanja. S obzirom na to da u odnosu na ostalo

${ }^{15}$ I. LAJIĆ - R. MIŠETIĆ, 2006, 367.

${ }^{16}$ Od 4. do 8. rujna 2013. i 5. studenog 2013.

${ }^{17}$ Deskriptivne statistike su procedure koje se koriste kako bi se sažele velike količine podataka. Pri tome se, u samo nekoliko podataka, osigurava razumijevanje velike količine podataka (I. ŠOŠIÍ - V. SERDAR, 2002, 10; N. BRACE et al., 2006, 7).

${ }^{18}$ Inferencijalne statistike koriste matematičke procedure kojima se pokušava procijeniti vjerojatnost da prikupljeni podaci podržavaju danu hipotezu (N. BRACE et al., 2006, 7). 
stanovništvo Srednje Like stanovnici grada Gospića vode drugačiji način života, pretpostavljeno je da će se njihovi rezultati značajno razlikovati u odnosu na ostale ispitanike. Uzorak ispitanika kod preostale dvije analizirane grupe približno je proporcionalan ukupnom broju stanovnika područja na koje se odnose. Time je analizirana grupa sjeverno područje, koja se odnosi na područje Općine Perušić i Grada Gospića (bez formalnog grada Gospića), po broju ispitanika najveća $(53,6 \%)$. S druge strane, analizirana grupa jugoistočno područje, koja obuhvaća područje Općine Lovinac, po broju ispitanika je najmanja $(18,2 \%)$.

Tab. 1. Analizirane grupe ispitanika prema broju i udjelu stanovnika pripadajućeg područja te broju i udjelu ispitanika

\begin{tabular}{|l|c|c|c|c|}
\hline Analizirana grupa & $\begin{array}{c}\text { Ukupni broj } \\
\text { stanovnika } \\
(2011 .)\end{array}$ & $\begin{array}{c}\text { Udio u ukupnom } \\
\text { broju stanovnika } \\
(2011 .)(\%)\end{array}$ & $\begin{array}{c}\text { Broj } \\
\text { ispitanika }\end{array}$ & $\begin{array}{c}\text { Udio u ukupnom } \\
\text { broju ispitanika (\%) }\end{array}$ \\
\hline grad Gospić (naselje) & 6575 & $40,1 \%$ & 31 & $28,2 \%$ \\
\hline sjeverno područje & 8808 & $53,7 \%$ & $59^{*}$ & $53,6 \%$ \\
\hline jugoistočno područje & 1007 & $6,2 \%$ & $20^{* *}$ & $18,2 \%$ \\
\hline
\end{tabular}

(izvor: www.dzs.hr, 2021-17-7; izračunato temeljem rezultata vlastitog anketnog ispitivanja)

*Mjesto prebivališta u naseljima Općine Perušić ima 37 ispitanika: Perušić (18 ispitanika), Donji Kosinj (6 ispitanika), Krš (4 ispitanika), Gornji Kosinj (4 ispitanika), Kvarte (2 ispitanika), Studenci (2 ispitanika), Mlakva (1 ispitanik), dok mjesto prebivališta u naseljima Grada Gospića ima 22 ispitanika: Lički Osik (5 ispitanika), Aleksinica (4 ispitanika), Bužim (3 ispitanika), Donje Pazarište (3 ispitanika), Popovača Pazariška (1 ispitanik), Široka Kula (2 ispitanika), Smiljan (2 ispitanika), Klanac (1 ispitanik), Kalinovača (1 ispitanik).

** Mjesto prebivališta u naseljima Općine Lovinac ima 20 ispitanika: Lovinac (10 ispitanika), Sv. Rok (7 ispitanika), Ličko Cerje (2 ispitanika) i Ričice (1 ispitanik).

\section{Obilježja uzorka ispitanika}

Uzorak provedenog anketnog ispitivanja sastoji se od 110 anonimnih ispitanika koji su odabrani jednostavnim slučajnim uzorkom metodom "na licu mjesta" (in situ) te su dalje u radu navedena obilježja uzorka. U ukupnom broju, najviše (41,8 \%) ispitanika je u dobnoj skupini 21-40 godina, manje $(36,4 \%)$ ih je u dobnoj skupini 41-60 godina, a najmanje (21,8 \%) ih je u dobnoj skupini 60 i više godina. $\mathrm{S}$ različitim udjelima zastupljenosti, takva 
distribucija ispitanika prema dobi prisutna je i u analiziranim grupama grad Gospić i sjeverno područje, dok su u jugoistočnom području sve dobne skupine zastupljene podjednako. U uzorku je zastupljeniji muški spol $(64,5$ \%) od ženskog (35,5 \%), što je (s različitim udjelima) slučaj i u svakoj od analiziranih grupa.

S obzirom na strukturu zaposlenosti, najviše ih je zaposlenih (46,4 \%), zatim umirovljenih (32,7\%) i nezaposlenih (16,4 \%), a najmanje je učenika, odnosno studenata (4,5\%). Takva je distribucija ispitanika prema zaposlenosti $\mathrm{s}$ različitim udjelima zastupljenosti prisutna i u analiziranim grupama grad Gospić i sjeverno područje. Međutim, kod jugoistočnog područja najzastupljeniji su umirovljenici, potom zaposleni i nezaposleni, a među ispitanicima nema učenika, odnosno studenata.

Pitanja o mjestu prebivališta ispitanika, odnosno o (eventualnom) doseljenju, postavljena su u anketnom upitniku kako bi se utvrdilo živi li ispitanik cijeli svoj život na području istraživanja ili je doselio. ${ }^{19} \mathrm{U}$ ukupnom broju ispitanika većina cijeli život živi u mjestu prebivališta $(72,7$ \%). Doseljenih je značajno manje: doseljenih iz drugih područja Republike Hrvatske (11,8 \%), iz drugog naselja Srednje Like $(6,4 \%)$, iz druge države $(4,6 \%)$ i iz druge općine Like $(4,5 \%)$. Takva distribucija ispitanika prema mjestu prebivališta ispitanika, odnosno prema (eventualnom) doseljenju, s različitim udjelima zastupljenosti, prisutna je i u analiziranim grupama grad Gospić i sjeverno područje. U jugoistočnom području većina cijeli život živi u mjestu prebivališta, a jednaki broj je doseljenih iz druge općine Like i iz drugih područja Republike Hrvatske, dok niti jedan od ispitanika nije doseljen iz drugog naselja Srednje Like ili iz druge države.

Potrebno je napomenuti kako su kao preduvjet pristupanju anketnom ispitivanju svakom potencijalnom ispitaniku postavljena tri predpitanja. Time su anketnom ispitivanju pristupili ispitanici koji imaju prebivalište na području Srednje Like, koji žive kontinuirano kroz duže vremensko razdoblje prije anketnog ispitivanja na području Srednje Like žive te kojima su posjedi na području Srednje Like u njihovom vlasništvu ili u vlasništvu nekoga iz njihovog kućanstva.

${ }^{19}$ Područje istraživanja je tijekom Domovinskog rata bilo okupirano te su mnogi u tom razdoblju živjeli izvan svojih naselja. Kako bi se uočila razlika između doseljenika i povratnika, prilikom anketiranja je za doseljenike postavljeno pitanje odakle su se doselili, dok je u ovom istraživanju za povratnike naznačeno kako su cijeli svoj život proveli u mjestu prebivališta. 


\section{Dobna struktura stanovništva Srednje Like}

Dobna struktura stanovništva Srednje Like je, kao i u većini drugih gorsko-planinskih područja Republike Hrvatske, vrlo nepovoljna. Prema posljednjem popisu stanovništva (2011.), na području Srednje Like je bilo $20,2 \%$ mladog stanovništva ( $0-19$ godina), zatim $50,1 \%$ zrelog stanovništva (20-59 godina) te $29,7 \%$ starog stanovništva ( $\geq 60$ godina) (Tab. 2 ). Indeks starenja, koji predstavlja omjer između starog i mladog stanovništva, je 2011. godine u Srednjoj Lici iznosio 147,2, što ukazuje na vrlo izražen stupanj ostarjelosti stanovništva. ${ }^{20}$ Naime, većina autora smatra da starenje stanovništva započinje kad vrijednost indeksa starenja premaši 35 ili 40. Nešto je povoljnije stanje zabilježeno u naselju Gospić koje je jedino gradsko u promatranom prostoru. Tamo je zabilježena vrijednost indeksa starenja od 102,2, što je osjetno povoljnije nego u ostalim prostornim sastavnicama Srednje Like, no i dalje se radi o izrazito nepovoljnoj vrijednosti promatranog pokazatelja. Ostale teritorijalne sastavnice bilježe osjetno nepovoljnije vrijednosti indeksa starenja pri čemu valja istaknuti da je ona u jugoistočnom dijelu Srednje Like (analizirana grupa jugoistočno područje) iznosila čak 276,1, što svjedoči o krajnje uznapredovalom stadiju starenja stanovništva.

Razmotri li se ostarjelost stanovništva prema metodologiji I. Nejašmića (2005.), dolazi se do sličnoga zaključka. Prema popisu stanovništva iz 2011. godine Srednja Lika je u cjelini zabilježila bodovni pokazatelj ostarjelosti od 60,5, što spada pod tip 5 ostarjelosti stanovništva čije je obilježje vrlo duboka starost. Iste je godine Hrvatska u cjelini imala bodovni pokazatelj ostarjelosti 67,0, što spada u nešto manje nepovoljan tip 4 ostarjelosti stanovništva čije je obilježje duboka starost. Naselje Gospić spada pod istu kategoriju ostarjelosti, s time da je bodovni pokazatelj neznatno povoljniji i iznosi 70,0. Ostale dvije prostorne sastavnice i temeljem ove metodologije bilježe znatno izraženiju razinu ostarjelosti stanovništva. Sjeverno područje ima bodovni pokazatelj ostarjelosti 55,5 što ga svrstava pod tip 5 ostarjelosti stanovništva čije je obilježje vrlo duboka starost, dok jugoistočno područje bilježi bodovni pokazatelj ostarjelosti od samo 42,0 što odgovara još nepovoljnijem tipu 6 ostarjelosti (izrazito duboka starost).

${ }^{20} \mathrm{Za}$ usporedbu, iste je godine indeks starenja za Hrvatsku u cjelini iznosio 115. 
Tab. 2. Dobna struktura stanovništva prema pripadajućem području analiziranih grupa ovog istraživanja

\begin{tabular}{|c|c|c|c|c|c|c|c|c|c|}
\hline \multirow{3}{*}{$\begin{array}{c}\text { Analizirana } \\
\text { grupa }\end{array}$} & \multicolumn{6}{|c|}{2011.} & \multirow{3}{*}{$\begin{array}{l}\text { Indeks } \\
\text { starenja }\end{array}$} & \multirow{3}{*}{$\begin{array}{c}\text { Bodovni } \\
\text { pokazatelj } \\
\text { ostarjelosti* }\end{array}$} & \multirow{3}{*}{$\begin{array}{c}\text { Tip } \\
\text { ostarjelosti* }\end{array}$} \\
\hline & \multicolumn{2}{|c|}{ 0-19 } & \multicolumn{2}{|c|}{$20-59$} & \multicolumn{2}{|c|}{$\geq 60$} & & & \\
\hline & Aps. & $\%$ & Aps. & $\%$ & Aps. & $\%$ & & & \\
\hline $\begin{array}{c}\text { grad Gospić } \\
\text { (naselje) }\end{array}$ & 1456 & 22,2 & 3631 & 55,2 & 1488 & 22,6 & 102,2 & 70,0 & $\begin{array}{l}4 \text { (duboka } \\
\text { starost) }\end{array}$ \\
\hline $\begin{array}{l}\text { jugoistočno } \\
\text { područje }\end{array}$ & 159 & 15,8 & 409 & 40,6 & 439 & 43,6 & 276,1 & 42,0 & $\begin{array}{c}6 \text { (izrazito } \\
\text { duboka } \\
\text { starost) }\end{array}$ \\
\hline $\begin{array}{l}\text { sjeverno } \\
\text { područje }\end{array}$ & 1694 & 19,2 & 4169 & 47,3 & 2945 & 33,5 & 173,8 & 55,5 & $\begin{array}{l}5 \text { (vrlo } \\
\text { duboka } \\
\text { starost) }\end{array}$ \\
\hline $\begin{array}{c}\text { SREDNJA } \\
\text { LIKA } \\
\text { UKUPNO }\end{array}$ & 3309 & 20,2 & 8209 & 50,1 & 4872 & 29,7 & 147,2 & 60,5 & $\begin{array}{l}5 \text { (vrlo } \\
\text { duboka } \\
\text { starost) }\end{array}$ \\
\hline
\end{tabular}

(izvor: www.dzs.hr, 2021-17-7)

* Prema Nejašmiću (2005.)

Zemljišni pokrov/način korištenja zemljišta i dobni sastav stanovništva Srednje Like

Analiza rezultata anketnog ispitivanja provedena je za dvije promatrane vremenske odrednice (trenutačno, tj. $\mathrm{u}$ vrijeme anketnog ispitivanja te kroz duže vremensko razdoblje prije anketnog ispitivanja). Pritom su procedurama deskriptivne statistike promatrani posjedi s obzirom na promatrana trenutna obilježja posjeda te s obzirom na tendenciju održavanja posjeda, koji su analizirani na dvije prostorne razine (analizirana grupa i Srednja Lika u cjelini), a procedurama inferencijalne statistike, preciznije metodom t-test, promatrani su međuodnosi dobnoga sastava i obilježja posjeda, koji su analizirani samo na prostornoj razini Srednja Lika u cjelini. 


\section{Trenutačna obilježja posjeda}

\section{Položaj voćnjaka i povrtnjaka}

Istraživanje je pokazalo kako se na području Srednje Like najviše voćnjaka i povrtnjaka nalazi samo uz kuću (70,0 \% voćnjaka; 71,8\% povrtnjaka). Naime, učestalo održavanje, odnosno obrada voćnjaka i povrtnjaka, razlog je zbog čega se oni nalaze uz kuću, tj. u mjestu stanovanja. Ostali položaji posjedovanih voćnjaka, odnosno povrtnjaka manje su zastupljeni. Također, manje su zastupljeni udjeli onih ispitanika koji ih ne posjeduju (10,9\% voćnjak; $6,4 \%$ povrtnjak).

Slična distribucija položaja voćnjaka i povrtnjaka utvrđena je kod svih analiziranih grupa. Pri tome, gotovo svi ispitanici analizirane grupe jugoistočno područje ih posjeduju te se najčešće nalaze samo uz kuću $(90,0 \% ; 85,0 \%)$. To je uvjetovano prirodnim preduvjetima (prostrano Lovinačko polje), odnosno većim parcelama uz kuću zbog čega se uz kuću nalaze pretežno svi voćnjaci i povrtnjaci pojedinog kućanstva. S druge strane, u odnosu na ostale analizirane grupe, ispitanici analizirane grupe grad Gospić ih posjeduje u najmanjem postotku (83,9\% voćnjak; 87,1\% povrtnjak) te se najrjeđe nalaze uz kuću (54,8 \% voćnjak; 51,6 \% povrtnjak), dok je značajni udio onih koji imaju voćnjake podjednako uz kuću i na posjedima udaljenim od kuće, kao i posjedovanje povrtnjaka pretežno na posjedima udaljenim od kuće. Kod analizirane grupe sjeverno područje je njihovo posjedovanje često (88,1 \% voćnjaka; $96,6 \%$ povrtnjaka) te su kao i kod ostalih grupa najčešće samo uz kuću $(71,2 \%$ voćnjaka; 77,9\% povrtnjaka), a ostali položaji posjedovanih voćnjaka, odnosno povrtnjaka su rjeđe zastupljeni. Nadalje, t-testom utvrđena je za Srednju Liku u cjelini značajna povezanost položaja povrtnjaka i dobi ispitanika $(t=2,802$; $\mathrm{df}=108 ; \mathrm{p}<0,01)$. Položaj povrtnjaka ispitanika Srednje Like se po dobi ispitanika razlikuje od slučajne, što znači da se položaj povrtnjaka ispitanika značajno razlikuje po njihovoj dobi. Stanovništvo starije dobi povrtnjake, koji su jednogodišnji, češće obrađuje uz kuću.

\section{Posjedovanje obradivog zemljišta u dragama}

Na području Srednje Like više od polovice ispitanika $(60,0 \%)$ ne posjeduje obradivo zemljište u dragama, odnosno ne posjeduje drage. S druge strane, oko četvrtina $(25,4 \%)$ ih ima mali dio obradivog zemljišta u dragama, dok je jednak broj $(7,3 \%)$ onih kojima se veći dio obradivog zemljišta nalazi 
u dragama te onih kojima se u dragama nalazi podjednaki dio obradivog zemljišta, kao i izvan njih.

S različitimudjelima je slična distribucija posjedovanja obradivog zemljišta u dragama prisutna i u analiziranim grupama grad Gospić i sjeverno područje. Međutim, u analiziranoj grupi jugoistočno područje 40,0\% ispitanika ne posjeduje drage, što je značajno manje u odnosu na ostale analizirane grupe ( 71,0 $\%$ grad Gospić; 61,0 \% sjeverno područje). Razlog tome su prirodni preduvjeti jer je na jugoistočnom području značajno više draga, odnosno ponikava nego što je to u ostalim analiziranim grupama, zbog čega se značajni broj ispitanika ove analizirane grupe izjasnio o posjedovanju obradivog zemljišta u dragama kao i izvan njih $(25,0 \%)$, zatim o posjedovanju manjeg dijela obradivog zemljišta u dragama (20,0 \%) te o posjedovanju većeg dijela obradivog zemljišta u dragama $(15,0 \%)$. Nadalje, t-testom utvrđena je za Srednju Liku u cjelini značajna povezanost posjedovanja obradivog zemljišta u dragama i dobi ispitanika $(\mathrm{t}=$ $11,167 ; \mathrm{df}=108 ; \mathrm{p}=0,00)$. Posjedovanje obradivog zemljišta u dragama kod ispitanika Srednje Like se po dobi ispitanika razlikuje od slučajne, što znači da se posjedovanje obradivog zemljišta u dragama značajno razlikuje po njihovoj dobi. Tako stanovništvo starije dobi zapušta obrađivanje zemljišta u dragama, koja su ipak udaljenija od kuće.

\section{Tendencija održavanja posjeda}

Utvrđivanje tendencija održavanja posjeda kroz duže vremensko razdoblje prije anketnog ispitivanja provedeno je pitanjima o održavanju, odnosno obrađivanju voćnjaka i povrtnjaka te obradivog zemljišta u dragama.

\section{Održavanje voćnjaka i povrtnjaka}

Na području Srednje Like tendencija održavanja voćnjaka razlikuje se od tendencije održavanja povrtnjaka. Naime, sve manje voćaka obrađuje 39,1 $\%$ ispitanika Srednje Like, trećina ih uzgaja podjednako, dok sve više voćaka uzgaja petina ispitanika. ${ }^{21} \mathrm{~S}$ druge strane, $\mathrm{u}$ tom razdoblju više od polovice ispitanika $(57,3 \%)$ obrađuje podjednaku površinu pod povrtnjacima, trećina ih obrađuje sve manju površinu, a sve veću površinu pod povrtnjacima obrađuje 9,1\% ispitanika. ${ }^{22}$ Time je vidljivo kako se na području Srednje Like uzgoj

${ }^{21} \mathrm{U}$ promatranom razdoblju najmanji broj $(8,2 \%)$ je onih koji u tom razdoblju nisu posjedovali voćnjak.

${ }^{22}$ Vrlo mali broj $(3,6 \%)$ ih je koji u promatranom razdoblju nisu posjedovali povrtnjake. 
povréa više održao nego što je to uzgoj voća. To je razumljivo s obzirom na to da se povrtnjaci sade kako bi se kroz više mjeseci različite vrste povrća uzgajale za vlastite potrebe. Gledajući tendenciju uzgoja voćnjaka i povrtnjaka prema analiziranim grupama, rezultati su pokazali kako kod svih analiziranih grupa distribucija tendencije obrađivanja površina pod povrtnjacima je kao i za područje Srednje Like u cjelini. Međutim, distribucija tendencije održavanja voćnjaka se među analiziranim grupama razlikuje - za grad Gospić i sjeverno područje rezultati prate distribuciju za područje Srednje Like u cjelini. To znači da u promatranom razdoblju najčešće uzgajaju sve manje voćaka, potom onih koji ih uzgajaju podjednako, a najmanje je onih koji uzgajaju sve više voćaka. Međutim, $\mathrm{u}$ analiziranoj grupi jugoistočno područje voćarstvo je zastupljenije u odnosu na druge dvije analizirane grupe, što govori u prilog tome da se to stanovništvo češće sadi voćke, koje su višegodišnje, tj. trajnije biljke. Tako su se svi ispitanici ove analizirane grupe izjasnili kako su u tom razdoblju posjedovali voćnjak, najviše $(40,0 \%)$ ispitanika ih je u promatranom razdoblju uzgajalo sve više voćaka, zatim je nešto manje onih koji je uzgajalo podjednako, a samo četvrtina ih je uzgajalo sve manje voćaka.

\section{Održavanje obradivog zemljišta u dragama}

Rezultati anketnog ispitivanje koji se odnose na tendenciju obrađivanja zemljišta u dragama kroz duže vremenskom razdoblju prije anketnog ispitivanja pokazali su da oko petine Srednje Like obrađuje sve manje obradivih površina u dragama, nešto manje (18,2 \%) ih obrađuje podjednako, a najmanje $(2,7 \%)$ ispitanika obrađuje sve veće obradive površine.

S različitim udjelima zastupljenosti, takva distribucija tendencije obradivih površina u dragama prisutna je i u analiziranim grupama grad Gospić i sjeverno područje. Međutim, u analiziranoj grupi jugoistočno područje najviše je ispitanika koji podjednako obrađuju obradive površine u dragama, nešto manje je onih koji ih u tom razdoblju nisu posjedovali, a slijede oni koji ih obrađuju sve manje. Kao i za područje Srednje Like u cjelini, tako je i u svim analiziranim grupama najmanje onih koji obrađuje sve veće obradive površine u dragama.

Za Srednju Liku u cjelini t-testom utvrđena je značajna povezanost tendencije održavanja obradivog zemljišta u dragama i dobi ispitanika $(\mathrm{t}=11,553$; $\mathrm{df}=108 ; \mathrm{p}=0,00)$. Tendencija održavanja obradivog zemljišta u dragama kod ispitanika Srednje Like se po dobi ispitanika razlikuje od slučajne, što znači da se tendencija posjedovanja obradivog zemljišta u dragama značajno razlikuje 
po njihovoj dobi. Naime, stanovništvo starije dobi češće zapušta obrađivanje zemljišta u dragama, koja su ipak udaljenija od kuće.

\section{Zaključak}

$\mathrm{U}$ radu je provedena analiza rezultata anketnog ispitivanja na uzorku ispitanika Srednje Like te demo(geo)grafska analiza podataka koji se odnose na dobnu strukturu stanovništva Srednje Like. Pritom su u anketnom ispitivanju promatrani položaj i posjedovanje, odnosno tendencija obrade voćnjaka, povrtnjaka te obradivog zemljišta u dragama, dakle odabranih pojedinačnih dijelova krajolika.

Procedurama deskriptivne statistike za dvije prostorne razine (analizirana grupa i Srednja Lika u cjelini) dobio se uvid u obilježja njihovog posjedovanja, zatim prostorne odnose te njihovo održavanje. Rezultati su pokazali kako se na području Srednje Like u cjelini sve manje obrađuju obradive površine u dragama i sve manje se sade voćnjaci. Međutim, podjednako se uzgajaju povrtnjaci, koji se najčešće nalaze uz kuću, te su manje površine i namijenjeni su uglavnom za vlastite potrebe. Ipak, takva slika nije ujednačena na cijelom području Srednje Like, pa promatrajući analizirane grupe vidljivo je kako analizirana grupa jugoistočno područje pokazuje zadržana ruralna obilježja te su ispitanici ove analizirane grupe sve više uzgajali voćke; podjednako obrađuju obradive površine u dragama i slično.

U radu su procedurama inferencijalne statistike, metodom t-test, istraženi odnosi dobnog sastava stanovništva na promjene zemljišnog pokrova/načina korištenja zemljišta, odnosno utječe li starenje stanovništva na njih. Rezultati su pokazali kako se položaj povrtnjaka, posjedovanje obradivog zemljišta u dragama i tendencija obrađivanja zemljišta u dragama razlikuju ovisno o dobi ispitanika. S druge strane, nije utvrđeno da se položaj voćnjaka razlikuje ovisno o dobi ispitanika kao niti da se tendencija uzgoja voćaka i povrća razlikuju ovisno o dobi ispitanika. Ako se promatra početna pretpostavka ovog rada, da je starenje stanovništva nepovoljni čimbenik promjene zemljišnog pokrova/ načina korištenja zemljišta Srednje Like te ima (nepovoljni) utjecaj u smislu smanjenja intenziteta obrade (što posljedično dovodi do zapuštanja krajolika), može se zaključiti da je to djelomično točno. Naime, rezultati su pokazali kako se tendencija uzgoja voćaka i povrća ne razlikuju ovisno o dobi ispitanika. Međutim, stanovništvo starije dobi sadi povrtnjake, koji su jednogodišnji i češće ih obrađuje uz kuću, a zapušta obrađivanje zemljišta u dragama, koja su ipak udaljenija od kuće. S druge strane, takvo stanovništvo voćnjacima, koji su 
višegodišnji (trajniji), ne mijenja položaj, odnosno ne sade ih, na primjer, bliže kuće. Dakle, iako je na području Srednje Like dobna struktura stanovništva, kao i u većini drugih gorsko-planinskih područja Republike Hrvatske, vrlo nepovoljna, u radu je utvrđeno kako se starenjem stanovništva Srednje Like ne smanjuje bavljenje svim poljoprivrednim djelatnostima.

\section{Literatura}

\section{Izvori}

Baza podataka za GIS shapefilove: Digitalni atlas Republike Hrvatske (DARH), Državna geodetska uprava (DGU), Zagreb

Baza podataka za GIS shapefilove: Središnji registar prostornih jedinica (SRPJ), Državna geodetska uprava (DGU), Zagreb

POPIS 2011., Državni zavod za statistiku (DZS), URL: www.dzs.hr (2021-17-7)

\section{Knjige i članci}

Biserka DUMBOVIĆ BILUŠIĆ, Prilog tumačenju pojma krajolika kao kulturne kategorije, Sociologija i prostor: Časopis za istraživanje prostornoga $i$ sociokulturnog razvoja, 52/2, Zagreb, 2014, 187-205.

Biserka DUMBOVIĆ BILUŠIĆ, Krajolik kao kulturno naslijeđe: metode prepoznavanja, vrjednovanja izaštite kulturnih krajolika Hrvatske, Ministarstvo kulture Republike Hrvatske, Uprava za zaštitu kulturne baštine, Zagreb, 2015.

Ante BLAĆE, Razvoj i suvremena preobrazba krajolika Ravnih kotara, Sveučilište u Zagrebu, Prirodoslovno-matematički fakultet, Geografski odsjek, Zagreb, 2015. (doktorski rad)

Ante BLAĆE, Promjene šumskoga pokrova na području Ravnih kotara u drugoj polovici 19. stoljeća, Hrvatski geografski glasnik, 81/2, Zagreb, 2019, 69-88.

Nicola BRACE - Richard KEMP - Rosemary SNELGAR, SPSS for psychologists: a guide to data analysis using SPSS for Windows, Lawrence Erlbaum Associates Mahwah, New Jersey, 2006.

Marin CVITANOVIĆ, Promjene zemljišnog pokrova i načina korištenja zemljišta u Krapinsko-zagorskoj županiji od 1978. do 2011., Sveučilište u Zagrebu, Prirodoslovno-matematički fakultet, Zagreb, 2014. (doktorski rad)

Anica ČUKA, Preobrazba dugootočkog krajolika kao odraz suvremenih sociogeografskih procesa, Sveučilište u Zadru, Odjel za geografiju, Zadar, 2010. (doktorski rad)

Zdenka DAMJANIĆ, Socioekološki aspekti vrednovanja mediteranskog krajolika: primjer otoka Krka, Godišnjak Titius: godišnjak za interdisciplinarna istraživanja porječja Krke, 6-7, Split, 2014, 169-194. 
Anamarija DURBEŠIĆ, Promjene pejzaža južne padine Svilaje - GIS pristup, Sveučilište u Zagrebu, Prirodoslovno-matematički fakultet, Zagreb, 2012. (doktorski rad)

Borna FUERST-BJELIŠ - Nikola GLAMUZINA, The Historical Geography of Croatia. Territorial Change and Cultural Landscapes, Springer International Publishing, Cham, 2021.

Borna FUERST-BJELIŠ, Reading the Venetian Cadastral Record: An Evidence for the Environment, Population and Cultural Landscape of the 18th century Dalmatia, Hrvatski geografski glasnik, 65/1, Zagreb, 2003, 47-62.

Borna FUERST-BJELIŠ - Sanja LOZIĆ - Marin CVITANOVIĆ - Anamarija DURBEŠIĆ, Promjene okoliša središnjeg dijela Dalmatinske zagore od 18. stoljeća, Proceedings, Zagora između stočarsko-ratarske tradicije te procesa litoralizacije i globalizacije, Zadar - Dugopolje, 2011, 19-21, 117-129.

Borna FUERST-BJELIŠ, Deforestacija i reforestacija u hrvatskome dinarskom kršu: Odnosi i implikacije, Ekonomska i ekohistorija, 14/1, Zagreb, 2018, 136-144.

Borna FUERST-BJELIŠ - Branimir VUKOSAV, Landscape of identities in shared spaces of the borderlands, Europa Regional, Leipzig, 2019, 5-13.

Marta HAMZIĆ - Borna FUERST-BJELIŠ - Mladen PAHERNIK, Strukturna obilježja uzoraka krajolika Srednje Like - primjena prostorne i regresijske analize, Kartografija i geoinformacije, Zagreb, 2020, 14-39.

Jósef HERNIK, Cultural landscape - across disciplines, Oficyna Wydawnicza BRANTA, Bydgoszcz-Kraków, 2009.

Angela IONITA - Cornel LEPADATU - Gabriela DUMITRESCU, Digital cultural landscape content, u: Jósef HERNIK (ur.), Cultural landscape - across disciplines, Oficyna Wydawnicza BRANTA, Bydgoszcz-Kraków, 2009, 255277.

Tomislav JOGUN - Katarina PAVLEK - Tomislav BELIĆ - Smiljan BUHIN - Nino MALEŠIĆ, Promjene zemljišnog pokrova u sjevernoj Hrvatskoj od 1981. do 2011. godine, Hrvatski geografski glasnik, 79/1, Zagreb, 2017, 33-59.

Tomislav JOGUN - Aleksandar LUKIĆ - Mateo GAŠPAROVIĆ, Simulation model of land cover changes in a post-socijalist peripheral rural area: Požega-Slavonia County, Croatia, Hrvatski geografski glasnik, 81/1, Zagreb, 2019, 31-59.

Marta JOVANIĆ, GIS analiza i razvojna tipologija krajolika Srednje Like, Sveučilište u Zagrebu, Prirodoslovno-matematički fakultet, Geografski odsjek Zagreb, 2017. (doktorski rad)

Branimir KRIŠTOFIĆ, Krajolik s kapitalom u pozadini: o akterima promjena u ruralnom prostoru na primjeru općine Lovinac, Sociologija i prostor: Časopis za istraživanje prostornoga i sociokulturnog razvoja, 48/2, Zagreb, 2010, 273 300. 
Ivan LAJIĆ - Roko MIŠETIĆ, Otočni logaritam, aktualno stanje i suvremeni demografski procesi na jadranskim otocima, Institut za migracije i narodnosti, Ministarstvo mora, turizma, prometa i razvitka, Zagreb, 2006.

Stefan LANG - Thomas BLASCHKE, Analiza krajolika pomoću GIS-a, ITDGaudeamus d.o.o., Požega, 2010.

Jelena LONČAR - Marin CVITANOVIĆ, (Post)socijalizam i okoliš: promjena kulturnog krajobraza Pridravske nizine Osijeka u posljednjih pedeset godina, Sociologija i prostor, 50/3, Zagreb, 2012, 327-343.

Damir MAGAŠ, Geografija Hrvatske, Manualia Universitatis Studiorum Iadertinae, Sveučilište u Zadru, Odjel za geografiju, Biblioteka Geographica Croatica, Meridijani Samobor, Zadar - Samobor, 2013.

Antonio MORIĆ-ŠPANIĆ - Borna FUERST-BJELIŠ, The GIS model for the revitalisation of traditional island cultures: the island of Hvar, Croatia, The Overarching Issues of the European Space: Society, Economy and Heritage in a Scenario Towards Greater Territorial Cohesion, Faculdade de Letras da Universidadedo Porto, Porto, 2017, 374-392.

Ivo NEJAŠMIĆ, Demogeografija, stanovništvo u prostornim odnosima i procesima, Školska knjiga, Zagreb, 2005.

Mladen PAHERNIK - Marta JOVANIĆ, Geomorphologic database in the function of the Central Lika landscape typology (Republic of Croatia), International Scientific Symposium: Hilly-mountain areas - problems and perspectives: zbornik radova, Makedonsko geografsko društvo, Skopje, 2014, 97-105.

Sushant PAUDEL - Fei YUAN, Assessing landscape changes and dynamics using patch analysis and GIS modeling, International Journal of Applied Earth Observation and Geoinformation, 16, Amsterdam, 2012, 66-76.

Dane PEJNOVIĆ, Srednja Lika: socijalnogeografska transformacija, Centar za kulturu - Muzej Like, Gospić 1985.

Veljko ROGIĆ, Geografija SR Hrvatske, Školska knjiga, Zagreb, 1975.

Ana SOPINA - Bojana BOJANIĆ OBAD ŠĆITAROCI, Asocijativna obilježja krajolika, Prostor: Znanstveni časopis za arhitekturu i urbanizam, 23/2, Zagreb, 2015, 304-313.

Ivan ŠOŠIĆ - Vladimir SERDAR, Uvod u statistiku, Školska knjiga, Zagreb, 2002.

Luka VALOŽIĆ - Marin CVITANOVIĆ, Mapping the forrest change: Using landsat imagery in forest transition analysis within the Medvednica protected area, Hrvatski geografski glasnik, 73/1, Zagreb, 2011, 245-255.

Arnold VAN DER VALK, Multiple cultural landscape: Research and planning for living heritage in the Netherlands, u: Jósef HERNIK (ur.), Cultural landscapeacross disciplines, Oficyna Wydawnicza BRANTA, Bydgoszcz-Kraków, 2009, 31-60. 


\section{THE INFLUENCE OF THE AGEING OF THE POPULATION ON CHANGES OF LAND COVER/METHODS OF LAND USE IN CENTRAL LIKA}

\section{Summary}

The impact of the ageing of the population on the changes in land cover/land use in Central Lika was analysed using an interdisciplinary approach - with the analysis of the results of a survey carried out on a sample of Central Lika respondents and the demo(geo)geographical analysis of data related to the age structure of the population of Central Lika. The interrelationships of land cover/land use and age of respondents were analysed on the spatial level of Central Lika as a whole using the t-test method within the IBM SPSS Statistics version 20 computer program. The results showed how the location of vegetable gardens, arable land ownership in the valleys and the inclination of the cultivation of the land in these valleys vary depending on the age of the respondents.

Keywords: the ageing of the population, land cover/land use, landscape, landscape development, Central Lika 